\author{
Przemysław Waszak \\ (Wydział Nauk Historycznych, \\ Uniwersytet Mikołaja Kopernika)
}

\title{
„Wstęp do historii sztuki” - przegląd najnowszej literatury
}

Przedstawione Wstępy do historii sztuki zostały napisane z punktu widzenia badaczy zajmujących się tą nauką w Niemczech i Wielkiej Brytanii. Sposób studiowania historii sztuki jest bowiem swoisty dla danego kraju. Młody adept historii sztuki wyniesie wiele korzyści z zapoznania się z tymi oryginalnymi, wzajemnie od siebie niezależnymi ujęciami.

Podstawowy, opracowany przez polskich autorów podręcznik Wstęp do historii sztuki wydano w 1973 r. $^{1}$ Niestety jak dotąd nie ukazały się wznowienia ani aktualizacje tej wciąż wartościowej publikacji. Cele historii sztuki jako jednej z nauk historycznych w odniesieniu do badań średniowiecza nakreśla niedawno w rozdziale Jarosław Jarzewicz ${ }^{2}$. Autor omawia uniwersalne pojęcia, przydatność dyscypliny w skondensowanej, wyjaśniającej wiele zagadnień formie. Należy odnotować niedawne opublikowanie tłumaczenia na język polski dwuczęściowego wstępu, który napisała Anne D’Alleva³.

Sergiusz Michalski zaznacza, że jego ujęcie - Wprowadzenie do historii sztuki $i^{4}$ nosi cechy świadomego wyboru zagadnień i proporcji ich przedstawienia. Taka konstatacja dobrze oddaje charakter każdego z omawianych wstępów. Okazuje się

1 Wstęp do historii sztuki, t. 1, Przedmiot - metodologia - zawód, red. Piotr Skubiszewski (Warszawa: Państwowe Wydawnictwo Naukowe, 1973).

2 Jarosław Jarzewicz, „Historia sztuki średniowiecznej”, w Vademecum historyka mediewisty, red. Jarosław Nikodem, Dariusz Andrzej Sikorski (Warszawa: Wydawnictwo Naukowe PWN, 2012), 409-425.

3 Anne D’Alleva, Jak studiować historię sztuki, tłum. Eleonora Jedlińska, Jakub Jedliński (Kraków: Towarzystwo Autorów i Wydawców Prac Naukowych Universitas, 2013); Anne D’Alleva, Metody i teorie historii sztuki, tłum. Eleonora Jedlińska, Jakub Jedliński (Kraków: Towarzystwo Autorów i Wydawców Prac Naukowych Universitas, 2008). Pierwodruk obu publikacji w języku polskim: 2008, drugie wydanie: 2013

4 Sergiusz Michalski, Einführung in die Kunstgeschichte (Darmstadt: WBG, 2015). 
bowiem, że jest to rozległy zespół kwestii, podatny na różne interpretacje, szczególnie w ostatnich latach. Podobnie istotne jest stwierdzenie Michalskiego, że jeszcze nie nadszedł czas, by sporządzić przekrojową syntezę ikonografii czy sztuki XX w. Ta uwaga prowadzi do wniosku, że w szerszym sensie naukowcy muszą nabrać dystansu do dziejów danej dyscypliny. Autor nie pominął też wszechogarniającej rewolucji cyfrowej ułatwiającej dostęp do reprodukcji dzieł sztuki.

Książka Michalskiego została wydana przez Wissenschaftliche Buchgesellschaft, którego hasło głosi „Wiedza łączy” - „Wissen verbindet”. To jedno z licznych wprowadzeń do poszczególnych nauk lub zagadnień w darmsztadzkim wydawnictwie. Autor przyjął formę spójnego wywodu podzielonego na rozdziały. Wybiórcze korzystanie z książki jest ułatwione dzięki umieszczeniu skróconych tytułów lub słów kluczowych na obszernych marginesach. Takie podsumowania umożliwiające orientację w toku rozumowania umieszczono na początku niemal każdego akapitu, rzadziej odnoszą się one do dwóch lub trzech następujących po sobie ustępów tekstu. Autor szczególnie dużo miejsca poświęcił strukturalizmowi Hansa Sedlmayra i myśli powojennych historyków sztuki, jak np. estetyce recepcji Wolfganga Kempa. Całość Wstępu... Michalskiego została podzielona na dziesięć bardziej rozbudowanych rozdziałów, krótką przedmowę i półstronicowe uwagi końcowe. Rozdziały wyjaśniają problemy naukowe w odniesieniu do historycznych przemian refleksji w ramach historii oraz konkretnych stanowisk badaczy. Rozważania Michalskiego oraz przywoływanych autorów pozwalają zobaczyć, czym dla pewnych myślicieli są poszczególne aspekty dzieł sztuki. Z publikacji wyłania się przemyślana, koherentna wieloaspektowość historii sztuki, ukazująca zalety, nowatorstwo, ale też słabości poszczególnych podejść metodologicznych. Autor eksponuje błędy badaczy, odwołując się do przykładu dokonanej przez Roberto Longhiego klasyfikacji tematu ikonograficznego obrazu Marco Zoppo, Strzelanie z łuku do zmarlego ojca z 1465 r. jako św. Krzysztofa. Nie ma zatem jednej obowiązującej wykładni dzieła sztuki ani jedynego właściwego podejścia do analizy problemów artystycznych. Książka prowadzi do konkluzji, że warto znać elementy różnych sposobów postępowania badawczego. Podejście historyzujące do dziejów interpretacji dzieła sztuki jest tu jednak najbardziej właściwe. Warto wspomnieć, że także interpretacje kluczowych historyków sztuki, takich jak Erwin Panofsky, niekiedy nie wytrzymały próby czasu. Można zauważyć, że również studenci patrzą na znaczenie dzieł sztuki przez pryzmat historii, przedstawiając na seminariach czy proseminariach wyczerpujące stany badań lub problemy artystyczne dotyczące poszczególnych obiektów, ich analiz, a następnie na ich podstawie formułują swoje opinie.

Zagadnienia przedstawione przez Michalskiego w pierwszych trzech rozdziałach książki ogniskują się wokół definicji historii sztuki i jej dziejów. W kolejnych częściach publikacji autor rozpatruje wciąż aktualne, bardziej współczesne podejścia badawcze w analizie dzieł sztuki. Najwięcej miejsca poświęca próbom analiz z punktu widzenia ikonografii, ikonologii, artystycznej typologii oraz motywiki. 
Omawiając ten temat, autor wskazuje międzykulturowe zależności sposobów zmiennego w czasie ujęcia tematów, pewną wspólnotę podejść ikonograficznych, a także nakreśla współczesne kierunki w ikonografii i ikonologii. Zwraca również uwagę na możliwości rozbieżnych interpretacji sensu obrazu.

Michalski niekiedy przytacza dłuższe fragmenty wypowiedzi uczonych. W omawianej publikacji nie znajdziemy jednak praktycznych wskazówek, jak się uczyć i jak studiować historię sztuki. Autor przechodzi do istoty rzeczy, czyli przedstawienia kluczowych pojęć, zmiennych definicji, sposobów myślenia poszczególnych badaczy, ich ujęć bądź najważniejszych spostrzeżeń. Wybór naukowców, którzy zapisali się w historii dyscypliny, jest szeroki i obejmuje nie tylko niemieckojęzycznych autorów. Michalski omawia bowiem również podejścia metodologiczne innych uczonych, jak dla przykładu koncepcję modi i tematów ramowych Jana Białostockiego, historię rzeczy George’a Kublera, a także metaobrazowość i samoświadomy obraz Victora Ieronima Stoichity. W książce pojawiają się też spostrzeżenia dotyczące pracy mniej znanych metodologów, by wymienić choćby Ernsta Michalskiego. Jeśli chodzi o bibliografię, to są w niej cytowane przede wszystkim tłumaczenia na język niemiecki prac poszczególnych uczonych, a nie ich pierwodruki w oryginale, co zapewne ma ułatwić niemieckojęzycznemu czytelnikowi dalszą orientację w poruszanych tematach.

Sergiusz Michalski odnosi się nie tylko do opublikowanej myśli badaczy, ale także do przełomowych wystaw artystycznych i mniej lub bardziej znanych dzieł sztuki - na przykład do malarstwa Caspara Davida Friedricha, obiektów artystycznych emblematycznych dla danych kierunków lub zjawisk artystycznych. Pokazuje, że adept historii sztuki często powinien zajmować się studium dzieł sztuki w terenie, a analizą obiektów tymczasowo niedostępnych lub nieosiągalnych - w bibliotece, korzystając przy tym z mających naukowy charakter, obszernych, nierzadko kilkutomowych katalogów wystaw i publikacji dotyczących poszczególnych muzealnych eksponatów. Michalski odwołuje się także do przykładów z zakresu kultury popularnej, reklamy wizualnej, by nakreślić, jak dana koncepcja ujmuje określone dzieło sztuki.

Autor postrzega dzieje historii sztuki przez pryzmat podejść do analizy obiektów artystycznych typowych dla kolejnych badaczy. Powstaje zatem diachroniczna polifonia ujęć metodologicznych, rozłożona na poszczególne, problemowe rozdziały. Tak pomyślaną pracę należy uznać za czyniącą historię historii sztuki, historiografię dyscypliny funkcjonalną, mającą walor praktyczny. Przedstawiona wiedza jest bowiem przydatna nie tylko w trakcie egzaminów teoretycznych ze Wstępu do historii sztuki i podczas teoretycznych kolokwiów z metodologii nauk o sztuce. Pojawiająca się podczas lektury książki Michalskiego refleksja nad ujęciami, wzbogacanymi niekiedy o konkretne przykłady oraz ilustracje, może wpłynąć na analizy dzieł sztuki dokonywane przez czytelnika i uczynić je doskonalszymi. Mierzenie się z obiektem artystycznym po fazie rzetelnego opisu ma szansę przybrać klarowne metodologicznie formy i pozwolić na umieszczenie dzieła sztuki 
na siatce zależności, a także lepiej odczytać wizualną strukturę obrazu. Podstawowym źródłem dla historyka sztuki jest dzieło sztuki, przedmiot zazwyczaj materialny. Z książki autora, w której zostały ukazane elementy myśli kilkudziesięciu badaczy, nie tylko historyków sztuki, wynika jednak, że to refleksja naukowa wyjaśnia lub nawet na nowo stwarza obiekty artystyczne znajdujące się we wzajemnym powiązaniu w świadomości odbiorców.

Historia sztuki w miarę rozwoju dyscypliny zaczynała obejmować coraz więcej obiektów artystycznych. Uwzględniano kolejne epoki artystyczne, a także sztukę niższych lotów ${ }^{5}$. Autor przedstawił i rozróżnił znaczeniowo szereg przejawów kiczu oraz parodii artystycznej. Należy zaznaczyć, że oryginalność dzieła sztuki to temat sporny i zajmujący wyobraźnię badaczy, odbiorców oraz osób dokonujących (nierzadko znacznych) operacji finansowych związanych z obiektami artystycznymi. Autor prześledził wiele kategorii naśladownictwa/kopii z podziałem na poszczególne dziedziny sztuki, np. grafikę. Zaprezentował również odmienne kategorie pojęciowe, odniósł się do nadal żywej dyskusji o falsyfikatach i „aurze” oryginalnego obiektu artystycznego oraz opisał postrzeganie kopii w poszczególnych epokach.

Następnie Michalski przeanalizował sytuację historii sztuki na początku XXI w. Wskazał problemy, dylematy i braki oraz zmienne podejście do analizy dzieł sztuki w podziale na analizowane epoki i zagadnienia, a także przedstawił nowe podejścia metodologiczne. W zakończeniu podkreślił relatywność i zależność przedmiotu badań historii sztuki od wielu czynników.

Za odpowiednik polskiego Wstępu... pod redakcją Piotra Skubiszewskiego, książki będącej owocem pracy cenionych naukowców, można uznać opublikowany po raz pierwszy w 1985 r. niemiecki podręcznik Historia sztuki. Wprowadzenie. Ta praca zbiorowa ukazała się nakładem wydawnictwa Reimer. Przedmiotem analizy będzie siódme, poszerzone i zmienione wydanie z 2008 r. ${ }^{6}$ Publikacja została podzielona na trzy części zawierające łącznie szesnaście autorskich rozdziałów oraz rozbudowane wprowadzenie na początku i krótsze, dołączone do części trzeciej. Poszczególne rozdziały zostały opatrzone obszernymi wskazówkami bibliograficznymi, odsyłającymi przede wszystkim do literatury niemiecko-, a rzadziej anglo-, francusko- włosko- lub węgierskojęzycznej, wskazującymi obok oryginałów ich tłumaczenia na język niemiecki. Autorzy podejmują w pierwszej kolejności zagadnienia związane z dorobkiem niemieckojęzycznej historii sztuki.

We wprowadzeniu Heinrich Dilly ${ }^{7}$ odpowiada w ujęciu historycznym na pytania m.in. o to, czym jest historia sztuki, kim są osoby, które ją tworzą, jak kształci się w jej ramach i jak rozwija się sama dyscyplina, a przy tym społeczność historyków sztuki oraz system powiązanych z nią instytucji.

\footnotetext{
Np. już: Andrzej Banach, O kiczu (Kraków: Wydawnictwo Literackie, 1968).

Hans Belting et al., red., Kunstgeschichte: eine Einführung (Berlin: Reimer, 2008).

Heinrich Dilly, „Einleitung”, w Belting, Kunstgeschichte, 9-19.
} 
Martin Warnke ${ }^{8}$ uwrażliwia czytelnika na dziedzinową złożoność przedmiotu badań historii sztuki: od architektury po szeroko pojęte rzemiosło artystyczne. Wskazuje na różnorodność: formalną, typologiczną, własnościową, związaną z charakterem użytkowania. Jego rozważania objęły ponadto celowość i funkcjonalną złożoność, a także różnorodność dzieł sztuki, ich ewolucję. Autor wskazał na wzajemne, międzyepokowe oddziaływanie obiektów artystycznych. Warnke zwraca uwagę na zacieranie się granic przy rozpatrywaniu dzieł sztuki. Według niego obiekty artystyczne mogą należeć do wspólnych zbiorów sfer, takich jak: prywatne/publiczne lub sakralne/świeckie/stanowiące wyraz władzy.

Willibald Sauerländer ${ }^{9}$ przestrzega przed pochopnymi konstatacjami. Autor podnosi rolę dokładnego, naukowego określenia oryginalności dzieła sztuki i jego charakterystycznych cech. Zaznacza, że obiekty artystyczne mają zmienną historycznie formę. Dokładne ustalenie podstawowych faktów odnoszących się do obiektu artystycznego - wymiarów, materiału, techniki - pozwala na wyciągnięcie ciekawych wniosków, np. na temat jego przynależności do kręgu geograficzno-artystycznego. Już w podstawowych zadaniach historyka sztuki przewija się u Sauerländera kwestia interdyscyplinarności oraz korzystania $\mathrm{z}$ wielu nauk pomocniczych. Autor podejmuje ponadto kwestię znawstwa.

Ulrich Schießl rozwija poruszony przez poprzednika temat. Omawia, w kontekście opieki nad zabytkami oraz podejścia konserwatorskiego, dokładne badania wstępne. Zakres m.in. techniczno-materiałowych badań obejmuje rzeźbę i malarstwo $^{10}$. Autor podkreśla konieczność korzystania $\mathrm{z}$ nauk przyrodniczych oraz przyrządów technicznych, stosowania precyzyjnej, jasnej i czytelnej terminologii. W kwestii malowideł wskazuje np. wielowarstwowość, przeróbki, uszkodzenia i możliwość ich badania za pomocą urządzeń, w tym całkowicie nieinwazyjnych. Schießl publikuje w znajdujących się w tekście głównym załącznikach z komentarzem przykładowe formularze-listy pytań i stwierdzeń, jakie można stworzyć w odniesieniu do dzieła sztuki, oraz sposoby przygotowania pomocniczej dokumentacji, a także dokonywania oglądu obiektów artystycznych.

Wprowadzające, niezbędne badania architektury przedstawił Dethard von Winterfeld ${ }^{11}$. Omówił specyfikę medium architektonicznego, które cechuje przestrzenność i wielopłaszczyznowość. Badacz uważa, że dzieła architektoniczne są złożone, wielowidokowe i wielowymiarowe. Odwzorowuje się je za pomocą fotografii, fotogrametrii, korzystając z metod stosowanych w archeologii. Do ich poznania pomocne jest sporządzanie planów, szkiców, przekrojów, przerysów, rzutów na płaszczyznę. Warto nadmienić, że studenci historii sztuki samodzielnie

\footnotetext{
8 Martin Warnke, „Gegenstandsbereiche der Kunstgeschichte”, w Belting, Kunstgeschichte, 23-48.

9 Willibald Sauerländer, „Die Gegenstandssicherung allgemein”, w Belting, Kunstgeschichte, 51-61.

10 Ulrich Schießl, „Materielle Befundsicherung an Skulptur und Malerei”, w Belting, Kunstgeschichte, 63-93.

${ }^{11}$ Dethard von Winterfeld, „Gegenstandssicherung an Architektur”, w Belting, Kunstgeschichte, 95-124.
} 
wykonują plany budowli. Autor wskazuje metody, techniki i pomoce służące pomiarom, określaniu wieku materiału, a także ich zalety i wady przedstawione na konkretnych przykładach. Winterfeld rozwija wywód o wskazówki pomagające w percepcji i opisie systemu dzieła architektonicznego. Pokazuje, że źródła pisane dostarczają pośrednich czy też mniej lub bardziej bezpośrednich wskazówek do dziejów budowli, zależnie od epoki, w której zostały sporządzone. Duże znaczenie mają rysunki, plany, inskrypcje, znaki kamieniarskie, modele.

W kolejnym rozdziale Sauerländer omawia datowanie, określanie miejsca pochodzenia i dalszych cech dzieł sztuki ${ }^{12}$. Według niego w kwestii datacji obiektów sztuki dawnej istnieje wiele znaków zapytania, nieścisłości, pojawiają się ponadto fakty burzące dotychczas ustalony porządek. Autor zwraca uwagę na wnioskowanie oparte na analogiach do dzieł, o których informacje zostały już potwierdzone. Ponadto podkreśla argumentowanie swoich propozycji badawczych i opisuje formułowanie rozwojowych ciągów stylistycznych w ramach twórczości osób i kręgów. Uważa, że istotne jest uwzględnianie zmiennej geografii artystycznej i możliwości celowych fałszerstw. Warto odnosić się do dat granicznych (w rodzaju terminus ante quem, terminus post quem), a podczas badań zwracać uwagę np. na historię mody i uzbrojenia oraz rozwój detali architektonicznych. Autor w swoim tekście kładzie nacisk na suwerenność historii sztuki, jej odrębność od innych dziedzin, pomimo wykorzystywania w niej metod stosowanych w wielu naukach pomocniczych. Podnosi problem odtworzenia złożonych kolei losu mobilnych, zmieniających funkcję i kontekst dzieł sztuki, a także ostrożnej analizy przesłanek, które mogą pomóc w odtworzeniu miejsca wykonania dzieła. Wskazuje również na potrzebę obiektywizmu w szczególności w kwestii przypisywania autorstwa, ostrzega przed poleganiem na odczycie sygnatur oraz porusza kwestię dzieł sztuki mających wielu współtwórców.

Najobszerniejszą część trzecią - „wykładnię” lub „interpretację” „przedmiotu” rozpoczyna krótkie wprowadzenie Hansa Beltinga i Wolfganga Kempa podkreślających różnorodność omówionych oraz zilustrowanych przykładami podejść badawczych ${ }^{13}$.

Hermann Bauer przedstawił analizę formalną dzieł sztuki ${ }^{14}$. Podjął temat opisywania i wyodrębniania formy, a zarazem klasyfikowania na przykładzie prac Johna Ruskina z połowy XIX w. Autor zaprezentował, stosując kilka cytatów, metodę strukturalistyczną Hansa Sedlmayra i przeciwstawił ją analizie stylistycznej. Omawiając historię stylu i analizy stylistycznej, przywołał najważniejszych przedstawicieli, stosujących metody formalne takich jak Alois Riegl, Heinrich

12 Willibald Sauerländer, „Alterssicherung, Ortssicherung und Individualsicherung”, w Belting, Kunstgeschichte, 125-152.

${ }_{13}$ Hansa Belting, Wolfgang Kemp, „Einleitung”, w Belting, Kunstgeschichte, 155-156.

14 Hermann Bauer, „Form, Struktur, Stil: Die formanalytischen und formgeschichtlichen Methoden", w Belting, Kunstgeschichte, 157-174. 
Wölfflin oraz Henri Focillon, a także genezę samego pojęcia stylu i ewolucję jego znaczenia oraz zakresu.

Wciąż stosowane metody ikonografii, ikonologii oraz ich kwestionariusz badawczy zaprezentował na przykładach Johann Konrad Eberlein ${ }^{15}$. Autor dokładniej omówił trzystopniowy schemat analizy dzieł sztuki zaproponowany przez Erwina Panofsky'ego oraz ważną w tym kontekście filozofię form symbolicznych Ernsta Cassirera $\mathrm{z}$ lat dwudziestych XX w. Eberlein wskazywał na odkrywanie sensu i znaczeń dzieł sztuki oraz na nieustanne odwoływanie, reinterpretowanie treści, form nawet o kilka epok wcześniejszych - np. form antycznych. Autor rozważa możliwości zajmowania się w ramach ikonologii zarówno sztuką popularną, jak i wysoką, do której należy szerzej omówiony, przepełniony symbolami miedzioryt Melancholia I Albrechta Dürera z 1514 r. Zostały tu skonfrontowane dwa podejścia do analizy graficznego arcydzieła.

Oskar Bätschmann zajął się hermeneutyką - swoistą, złożoną, dokładną, refleksyjną interpretacją, percepcją i wyjaśnieniem, zrozumieniem „dzieł sztuki jako dzieł sztuki”"16, a następnie umieszczaniem ich na siatkach zależności. Autor w swoim wywodzie zastosował metodę prezentowania skondensowanych, kluczowych, jednozdaniowych wykładni poszczególnych aspektów, które następnie obszernie komentował i argumentował. Autor proponuje sporządzanie listy pytań do kształtu artystycznego każdego obrazu, w szczególności odnoszących się do najmniej zrozumiałych aspektów struktury przedstawienia. We wszechstronnej, uporządkowanej, opierającej się na możliwie wielu przesłankach analizie obrazu Nicolasa Poussina wykorzystuje krytycznie źródła literackie oraz m.in. komentarz odautorski malarza. Przedstawia obszernie studium indywidualnego przypadku postrzeganego z punktu widzenia hermeneutyki obrazowej, którego elementy mogą posłużyć przy konstruowaniu własnych rozważań nad kolejnymi obiektami artystycznymi.

Hans Belting omówił kontekst, specyfikę odbiorców oraz funkcje dzieł sztuki i powiązania między nimi ${ }^{17}$. Autor zauważa współzależności kontekstów i formy, gatunku dzieła sztuki i pokazuje je przede wszystkim na przykładzie wyrwanego z oryginalnego kontekstu sieneńskiego obrazu Maestà pędzla Duccia di Buoninsegna z początku XIV w., który stanowi punkt wyjścia do określenia roli włoskich obrazów tablicowych, ich typów i funkcji samego obrazu w średniowieczu. Belting rozważa pierwotny kształt, podobne wzory, jak również analogie obrazowe, intencjonalny przekaz i kontekst dzieła Duccia, w tym także kontekst przestrzenny i uwzględniający pozostałe elementy wyposażenia katedry.

15 Johann Konrad Eberlein, „Inhalt und Gehalt: Die ikonografisch-ikonologische Methode”, w Belting, Kunstgeschichte, 175-197.

16 Oskar Bätschmann, „Anleitung zur Interpretation: Kunstgeschichtliche Hermeneutik”, w Belting, Kunstgeschichte, 199-228.

17 Hans Belting, „Das Werk im Kontext”, w Belting, Kunstgeschichte, 229-246. 
Temat estetyki recepcji podjął Wolfgang Kemp ${ }^{18}$. Autor rozpoczyna swoje rozważania od dłuższego cytatu z powieści Proces Franza Kafki, w której jest opisana dokonywana przez głównego bohatera literackiego uważna, powolna percepcja obrazów znajdujących się w kaplicy. Kemp zwraca uwagę na pierwotny kontekst przestrzenny obrazów oraz na specyfikę samej złożonej grupy odbiorców dzieł sztuki. Wyjaśnia jednocześnie zakres omawianej metody oraz przywołuje dyscypliny pokrewne do obrazowej estetyki recepcji. Naukowiec analizuje dialogi, relacje, jakie pojawiają się w różnych konfiguracjach, na drodze obraz-odbiorca. Sugestywnym, omówionym przykładem jest obraz i szkic Podsłuchująca.

Kwestię „historii społecznej” w odniesieniu do dzieł sztuki przedstawił Norbert Schneider ${ }^{19}$. Autor zauważa, że sztuka wynika z uwikłania jej oraz artystów ją tworzących w potrzeby i zagadnienia społeczne, światopoglądowe, odmienne ideologie oraz interesy. Szczegółowo rozwija m.in. socjologiczne, kulturowe, ekonomiczne, dotyczące grupy społecznej, statusu, świadomości i funkcji społecznych, prawne aspekty sztuki oraz ich tradycję badawczą. Klasyfikacje analizowane przez Schneidera odróżniają się od innych występujących w historii sztuki, np. stylistycznych.

Barbara Paul podjęła siępokazania historii sztuki z perspektywy feministycznej oraz studiów genderowych ${ }^{20}$. Omówiła okoliczności powstania i drogę wykształcenia się women's studies, których zakres nie zawęża się tylko do sztuki i nauki tworzonej przez kobiety. Autorka przedstawiła także naukowe poddziedziny, takie jak studia postkolonialne. Paul stawia, w kontekście posiadających rozwinięty dorobek naukowy badań feministycznej historii sztuki, pytanie o twórcę, proces oglądu, kategorie płci, dzieło sztuki. Postuluje potrzebę korekty, wzbogacenia dyskursu naukowego, zespołu pojęć oraz sposobu podejścia do roli kobiet w rozwoju sztuki. Ponadto analizuje - z omawianej perspektywy metodologicznej $\mathrm{i}$ historycznej - stereotypy, znaczenia i liczne przedstawienia obrazowe, a także działania artystyczno-społeczne.

Karl Clausberg zajął się postrzeganiem dzieł sztuki za pomocą nauk neuronowych oraz m.in. kontekstów optycznych, stereoskopowych, psychologicznych, dotyczących aparatu i procesów ludzkiego widzenia ${ }^{21}$. Elementy koncepcji takiego podejścia do złożonego zjawiska percepcji sięgają XIX w. Stosowali je również artyści tacy jak René Magritte, tworząc rzeczywistość obrazową i prowadząc swoistą grę $\mathrm{z}$ widzem. Ze wspomaganych komputerowo nauk o procesach mózgowych, kognitywistyki czerpie także historia sztuki czy też - jak rzecz ujmuje autor - „interdyscyplinarne nauki o obrazie".

18 Wolfgang Kemp, „Kunstwerk und Betrachter: Der rezeptionsästhetische Ansatz”, w Belting, Kunstgeschichte, 247-265.

19 Norbert Schneider, „Kunst und Gesellschaft: Der sozialgeschichtliche Ansatz”, w Belting, Kunstgeschichte, 267-295.

20 Barbara Paul, „Kunstgeschichte, Feminismus und Gender Studies”, w Belting, Kunstgeschichte, 297-336.

${ }^{21}$ Karl Clausberg, „Neuronale Bildwissenschaften”, w Belting, Kunstgeschichte, 337-362. 
Wizualne przekaźniki treści to tytuł rozdziału Horsta Bredekampa ${ }^{22}$. Autor przedstawił wstęp do historii sztuki, opierając się na koncepcjach rodzajów „mediów obrazowych" oraz materiałów artystycznych. Ta problematyka została podjęta już przez sztukę chrześcijańską u jej zarania. Rozważano wówczas dopuszczalność, a następnie formy materialnych przedstawień boskich i świętych. Bredekamp omówił w tym kontekście znaczenie następujących stopniowo i sukcesywnie rozwijających się rewolucji: fotograficznej, filmowej, cyfrowej oraz internetowej, a także stosunek historyków sztuki do tych przemian.

Kwestie postmodernizmu, w tym dekonstrukcjonizmu i poststrukturalizmu, powiązań z postkolonializmem, a także Nowej Historii Sztuki podjął László Beke ${ }^{23}$. Autor wychodzi od podstawowych zadań historii sztuki jako nauki o obiektach i procesach artystycznych, co prowadzi do stwierdzenia o przemianach czy nawet o kryzysie tej dyscypliny, jej nowych interpretacjach. Beke wyjaśnia zawarte w tytule definicje w kontekście historii sztuki oraz stylistyki i przemian artystycznych, kwestionowania oraz przewartościowania dawnych pojęć, takich jak np. „autorstwo”, „oryginalność”, „plagiat w sztuce”, a także pojawienia się nowych środków wyrazu artystycznego i kolejnych perspektyw metodologicznych, myślowych.

Dopełnianie zrozumienia historii sztuki przez nauki pokrewne, zbliżone i pomocnicze wyjaśnia Heinrich Dilly ${ }^{24}$. Autor postuluje zacieśnienie interdyscyplinarnej współpracy i bierze w tej kwestii pod uwagę liczne dziedziny wiedzy posługujące się innym językiem oraz odmiennie traktujące przedmiot własnych badań. Dilly podkreśla przy tym, że wszystkie gałęzie wiedzy mają wspólne cechy, stosują aparat naukowy.

Inny rodzaj wprowadzenia zaprezentował Hermann Bauer w swojej publikacji Historia sztuki. Krytyczne wprowadzenie do studiowania historii sztuki $i^{25}$. Zrezygnował ze wskazówek praktycznych. Przedstawił szereg problemów, ramowych klasyfikacji ważnych dla historii sztuki. Jego książka pokazuje, jak można rozumieć problemy historii sztuki, odpowiada na pytanie, co stanowi esencję studiowania. Autor posłużył się licznymi cytatami, m.in. z prac Hansa Sedlmayra i Mircea Eliadego. Sformułował własne oceny omawianych kwestii. Pokazał metody myślenia, proponując np. „eksperyment myślowy” dotyczący uznania za dzieło dziewiętnastowieczne słynnego, późnogotyckiego ołtarza z Isenheim, autorstwa Matthiasa Grünewalda. Omawiane przez badacza tematy i podejmowane kwestie mogą być jeszcze nie dość dobrze znane osobie rozpoczynającej studia z historii

22 Horst Bredekamp, „Bildmedien”, w Belting, Kunstgeschichte, 363-386.

23 László Beke, „Postmoderne Phänomene und New Art History”, w Belting, Kunstgeschichte, 387-407.

24 Heinrich Dilly, „Wechselseitige Erhellung - Die Kunstgeschichte und ihre Nachbardisziplinen", w Belting, Kunstgeschichte, 409-423.

${ }_{25}$ Hermann Bauer, Kunsthistorik. Eine kritische Einführung in das Studium der Kunstgeschichte (München: C.H. Beck, 1989). Kunsthistorik to w sensie szczegółowym nauka metod stosowanych w historii sztuki. 
sztuki. W trakcie edukacji uniwersyteckiej zasygnalizowane przez Bauera zagadnienia, takie jak problem ruiny u romantycznego malarza Caspara Davida Friedricha, geneza bazyliki wczesnochrześcijańskiej, ikonoklazm powinny zostać rozwinięte. Studenci podczas wykładów i konwersatoriów oraz samokształcenia będą mogli zapoznać się nie tylko z komentarzami naukowymi do omawianych zagadnień, ale i z tekstami źródłowymi. Będą mieli okazję porównać wiele źródeł wizualnych - obiektów artystycznych - tworzących ciągi rozwojowe. Autor zwraca uwagę, że historia sztuki jest „porządkowaniem”, jednak własny system nauki i podejścia do dzieł sztuki każdy student musi wypracować sam. Logiczna, przejrzysta i rzeczowa konstrukcja pracy Bauera stanowi pewną pomoc w tym zakresie. Autor zwraca uwagę na uproszczenia myśli, jakie niesie ze sobą ujmowanie zagadnień w tabele lub schematy. Omawiana książka wpisuje się w szereg licznych wprowadzających, propedeutycznych ujęć charakterystycznych dla akademickiej dydaktyki niemieckiej ${ }^{26}$. Powinna stanowić punkt wyjścia i zachętę do głębszego zajęcia się zarysowanymi w niej zagadnieniami. Charakterystyka wywodów w publikacji Bauera pozwala porównać je do przedstawienia w ujęciu historycznym dziejów myśli, filozofii i metodologii historii sztuki. Z książki stopniowo wyłania się złożoność dyscypliny, panoramiczny zarys, wokabularz problemów, punktów, wokół których ogniskuje się uwaga historyków sztuki. Autor stara się nakreślić relacje pomiędzy dyscyplinami pokrewnymi i naukami pomocniczymi, przedstawić wiele różnych aspektów. Ukazuje, czym jest historia sztuki jako nauka akademicka. Ponadto kilkukrotnie stosuje schemat trójkąta, który najlepiej odzwierciedla wzajemne, wielokierunkowe zależności. Za przydatne należy uznać liczne klasyfikacje, takie jak podział na źródła bezpośrednie i odnoszące się nie wprost do przedmiotu badań historii sztuki. Punktem wyjścia i zarazem punktem odniesienia tej publikacji jest przede wszystkim dorobek niemieckojęzycznej historii sztuki.

Temat wprowadzenia do historii sztuki podjęła również Marcia Pointon w publikacji Historia sztuki. Podręcznik studenta ${ }^{27}$. W 2014 r. ukazało się piąte wydanie jej książki. Wstęp został napisany z perspektywy brytyjskiego systemu szkolnictwa i warunków nauczania oraz sposobu prowadzenia badań. Podręcznik obfituje w wiele interesujących, uniwersalnych, przydatnych spostrzeżeń i zawiera wiele odniesień do współcześnie żyjących postaci, znanych twórców, Internetu, serwisu YouTube. Taka aktualizacja kontekstów ma na celu uprzystępnienie młodemu adeptowi nauk humanistycznych wprowadzenia, którego pierwodruk został wydany w $1980 \mathrm{r}$.

Jedno ze stereotypowych pytań zaprezentowanych w książce dotyczy tego, czy studenci lub historycy sztuki uprawiają sztukę. Trzeba przyznać, że wśród studentów historii sztuki znajdują się osoby, które ukończyły licea plastyczne i mają pewne

26 Np. Frank Büttner, Andrea Gottdang, Einführung in die Ikonographie: Wege zur Deutung von Bildinhalten (München: Verlag C.H. Beck, 2013); Stilfragen zur Kunst des Mittelalters: eine Einführung, red. Bruno Boerner, Bruno Klein (Berlin: Reimer, 2006).

27 Marcia Pointon, History of Art. A Student's Handbook (London-New York: Routledge, 2014). 
przygotowanie. Należy również podkreślić, że zainteresowanie historią sztuki rozpoczyna się często od książki O sztuce Ernsta Hansa Gombricha ${ }^{28}$. To charakterystyczne także dla miłośników tej dziedziny w Polsce. Oczywiście można zaczynać przygodę z historią sztuki bardzo wcześnie, od innych, także popularnonaukowych publikacji, przede wszystkim od ilustracji w nich zawartych, luźnych fotografii, kart pocztowych czy wizyt w muzeach. Pointon kilkukrotnie wskazuje na to, by studenci przyjmowali wiedzę pochodzącą z Internetu szczególnie ostrożnie. Teksty internetowe często wprowadzają w błąd, przekazując nieprawdziwe informacje, i nie można ich porównywać do poważnych naukowych prac. Autorka podkreśla jednak, że Internetu nie można też nie doceniać i odsyła czytelnika do wielu stron znajdujących się w sieci. Dzięki nim bowiem część rozproszonych informacji, które trzeba by zbierać podczas kwerend w rozsianych po świecie bibliotekach, fototekach i muzeach, jest dostępna na wyciągnięcie ręki, co służy zarówno pracownikom naukowym przygotowującym dla studentów materiały do dyskusji czy analiz, jak i samym studentom.

Studenci historii sztuki muszą operować precyzyjnym, fachowym językiem i odpowiednią terminologią służącą im do opisu wizualnych przedstawień. Pomocny okazuje się tu szereg słowników terminologicznych ${ }^{29}$. Adepci historii sztuki zaznajamiają się z nimi stopniowo, np. poprzez wykonywanie cotygodniowych opisów malarstwa, rzeźby, rzemiosła artystycznego, nastaw ołtarzowych, obiektów artystycznych znajdujących się w przestrzeni kościelnej oraz wnętrz i elewacji architektonicznych. Uzupełnieniem prowadzonych zajęć w terenie może być systematyczne wykonywanie zadań sprawdzających opanowanie przez studentów terminologii. Polegają one na nazwaniu, opisaniu wydrukowanych ilustracji przedstawiających detale architektoniczne, ornamenty, elementy budowli z różnych epok oraz typy ikonograficzne. Pointon w swojej publikacji zaprezentowała szereg wybranych, odmiennych przykładów dyskursu o sztuce, wyróżniając terminy i sposoby ich użycia, które mogą brzmieć obco lub niecodziennie. Historia sztuki, podejmując różnorodną problematykę, z natury wykorzystuje słownictwo i definicje z zakresu innych dyscyplin humanistycznych, a nawet posiłkuje się nazewnictwem stosowanym w naukach ścisłych.

28 Ernst Hans Gombrich, O sztuce, tłum. Monika Dolińska et al. (Warszawa: „Arkady”, 1997).

29 Ze słowników ogólnych np. Wilfried Koch, Style w architekturze. Arcydzieła budownictwa europejskiego od antyku po czasy współczesne, tłum. Waldemar Baraniewski et al. (Warszawa: Świat Książki, 1996) [kilka wydań]; Krystyna Zwolińska, Zasław Malicki, Mały słownik terminów plastycznych (Warszawa: Wiedza Powszechna, 1990) [kilka wydań]; Wiesław Rządek, Konrad Tomaszewski, Podręczny słownik historyka sztuki: ornamentyka i motywy dekoracyjne (Poznań: Instytut Historii Sztuki UAM, 1991); Słownik terminologiczny sztuk pięknych, red. Krystyna Kubalska-Sulkiewicz, Monika Bielska-Łach, Anna Manteuffel-Szarota (Warszawa: Wydawnictwo Naukowe PWN, 2005) [wiele wydań]; Słownik terminów, Sztuka świata, t. 17, 18 (Warszawa: Wydawnictwo Arkady, 2013); Słownik terminologiczny sztuk pięknych, red. Stefan Kozakiewicz (Warszawa: Państwowe Wydawnictwo Naukowe, 1976) [dwa wydania]; Fritz Winzer, Słownik sztuk pięknych, tłum. Janina Kumaniecka (Katowice: „Książnica” 2000) [dwa wydania]. 
Ostatni rozdział wprowadzenia Pointon to kilkanaście opatrzonych komentarzem opisów karier osób, które niedawno studiowały historię sztuki. Takie ujęcie, mające zachęcić do studiowania historii sztuki, ma swój odpowiednik w Polsce. Jest nim Galeria absolwentów zamieszczona na stronie internetowej Katedry Historii i Sztuki i Kultury UMK ${ }^{30}$. Przedstawione osoby opowiadają tam o własnej drodze studenckiej, zawodowej, naukowej i o tym, jakie cele udało im się zrealizować dzięki ukończeniu studiów na kierunku historia sztuki. Warto zaznaczyć, że adepci każdej nauki czerpią z wiedzy, warsztatu i osobowości swoich prowadzących. Dlatego tak wartościowe dla studenta danej dyscypliny może okazać się czytanie wspomnień o nich lub autobiograficznych wypowiedzi. W tej tematyce za niezwykle cenne należy uznać artykuły Moja historia sztuki doświadczonych profesorów historii sztuki, mediewistów ${ }^{31}$. Tego rodzaju prace zawierają opisy drogi naukowej, osiągnięć, radzenia sobie z przeciwnościami, życia w trudnych czasach, zasług, stosowanej metodologii oraz wizji sztuki. Wizerunek naukowca ${ }^{32}$ wyłaniający się z takich licznie ukazujących się $e^{33}$ opracowań to ciekawe zagadnienie. Na etapie studiowania, zgłębiania spektrum historii sztuki, czytania prac naukowych i udziału w zajęciach tego typu publikacje mają większą wartość aniżeli opowiadania o wykonywaniu zawodu po uzyskaniu uniwersyteckiego dyplomu. Dobór relacji historyków sztuki w publikacji Pointon, ale też wspomniana Galeria absolwentów udowadniają elastyczność osób z uniwersyteckim dyplomem historii sztuki. Wiąże się to z gruntownymi, wszechstronnymi studiami z dziedziny nauk humanistycznych.

Susanna Partsch opublikowała Wprowadzenie do studiowania historii sztuki w serii tomików Universal-Bibliothek ${ }^{34}$. To rozbudowana, składająca się z różnych części seria wydawnicza monograficznych książek małego formatu. W jej ramach wydano także np. Biblię w sztukach przedstawiających ${ }^{35}$, omówienia poszczególnych epok artystycznych, np. romanizmu ${ }^{36}$, oraz inne pozycje, np. Leksykon symboli i atrybutów w sztuce $e^{37}$.

We wprowadzeniu Partsch można znaleźć stwierdzenie, że historyk sztuki zawsze zabiera ze sobą w podróż katalog zabytków Dehio obejmujący miejscowość lub region, do którego się udaje. Jego odpowiednikiem w Polsce są np. tomy serii

30 Katedra Historii Sztuki i Kultury UMK, „Galeria Absolwentów”, http://www.historiasztuki. umk.pl/joomla/index.php?option=com_content\&view=article\&id=112\&Itemid=63, dostęp: 29 XII 2017.

31 Piotr Skubiszewski, „Moja historia sztuki”, Modus. Prace z Historii Sztuki 14 (2014): 5-22; Jerzy Gadomski, „Moja historia sztuki”, Modus. Prace z Historii Sztuki 15 (2015): 7-13.

32 Przemysław Waszak, „Ideał uczonego. Autobiograficzny obraz naukowca”, Forum Akademickie, nr 12 (2009): 58-59.

33 Poświęcono temu zagadnieniu ostatnio dwa tomy: Rocznik Historii Sztuki 36 (2011) oraz Rocznik Historii Sztuki 37 (2012).

34 Susanna Partsch, Einführung in das Studium der Kunstgeschichte (Stuttgart: Reclam, 2014).

35 Christoph Wetzel, Die Bibel in der bildenden Kunst (Stuttgart: Philipp Reclam jun., 2009).

${ }_{36}$ Kunibert Bering, Romanik (Stuttgart: Philipp Reclam jun., 2004).

37 Hildegard Kretschmer, Lexikon der Symbole und Attribute in der Kunst (Stuttgart: Reclam, 2014). 
Katalog zabytków sztuki w Polsce ${ }^{38}$ i prace Jerzego Z. Łozińskiego ${ }^{39}$. Niewątpliwym błędem studentów znajdujących się na początku akademickiej edukacji jest poprzestawanie na takich publikacjach przy przygotowywaniu pierwszych referatów. Tymczasem prace z zakresu literatury przedmiotu mogą stanowić dobry punkt wyjścia do dalszych poszukiwań i wzbogacania wywodów o kontekst. Podobnie zresztą jak monografie sztuki danego miasta lub regionu. Co istotne, nie tylko turyści mogą wynieść wiele informacji o zabytkach, ich lokalizacji i wstępnej klasyfikacji z przydatnego i obszernego - oraz podobnie jak katalogi Dehio zabieranego w podróże - Słownika geograficzno-krajoznawczego Polski, który do 2000 r. doczekał się czterech wydań ${ }^{40}$. Podobnie warto zapoznawać się z przewodnikami, niekiedy pisanymi przez historyków sztuki lub historyków, zarówno współczesnymi, jak i dawnymi, zawierającymi informacje o dziełach sztuki sprzed kilkudziesięciu, a niekiedy nawet prawie dwustu lat. To samo dotyczy dawnych relacji z podróży i innych form wypowiedzi pisanej.

Partsch rozpoczęła wprowadzanie w zakres historii sztuki od przedstawienia jej nowożytnych początków poprzez prezentację osoby Giorgia Vasariego. Wśród omówionych poza Vasarim jedenastu „słynnych historyków sztuki” znaleźli się jednak wyłącznie badacze, których pierwszym językiem jest niemiecki. Autorka obok omówienia wkładu w historię sztuki oraz innych faktów z życia znanych osobistości przytoczyła dość obszerne fragmenty ich najważniejszych wypowiedzi.

W kolejnej części autorka pokazuje w podziale na poszczególne punkty sposób odczytania kilku dzieł sztuki. Podstawowym zadaniem zajęć ze wstępu do historii sztuki jest kształcenie rzetelnego, użytecznego, dalekiego od subiektywizmu opisu dzieł m.in. malarstwa, rzeźby, architektury, grafiki, rysunku, instalacji artystycznych wykonanych w odmiennych technikach, o różnej tematyce, ujęciu i datowaniu, przynależności do epoki stylistycznej, sposobu podejścia do wykreowania artystycznej rzeczywistości przedstawionej przez twórcę w jego dziele sztuki. W kolejnych latach na tej solidnej podbudowie rozwija się umiejętności dalszej analizy, komparatystyki, heurystyki, wzbogacania o kontekst i monograficznego opracowywania dzieł sztuki oraz problemów artystyczno-kulturowych.

Partsch zastosowała w swojej pracy czytelny, punktowy podział analizy dzieła sztuki. Obejmuje on m.in. ustalenie podstawowych faktów, analizę stylistyczną, ikonograficzną, ikonologiczną. Ułatwia studentowi badanie obiektów artystycznych. Należy pamiętać, że każde dzieło sztuki nosi przede wszystkim cechy indywidualne i wymyka się schematom. Autorka w kolejnych rozdziałach omawia podział dzieł sztuki według ich rodzajów i epok artystycznych. Sygnalizuje szereg podstawowych

38 Np. Katalog Zabytków Sztuki w Polsce, redakcja naczelna Maria Kałamajska-Saeed, seria nowa, t. 8, Miasto Gdańsk, cz. 1-2, Główne Miasto, red. Barbara Roll, Iwona Strzelecka (Warszawa: Instytut Sztuki Polskiej Akademii Nauk, 2006).

39 Np. Jerzy Zygmunt Łoziński, Pomorze, Pomniki sztuki w Polsce, t. 2, cz. 1 (Warszawa: Arkady, 1992).

40 Np. Stownik geograficzno-krajoznawczy Polski, red. Maria Irena Mileska (Warszawa: Wydawnictwo Naukowe PWN, 1994). 
operacji myślowych, klasyfikacyjnych, porządkujących, jakie można wykonać względem dzieła sztuki, a także pytań, które pojawiają się w obliczu różnych problemów artystycznych. Partsch przekazuje pewne elementy, właściwie rudymenty, wiedzy ogólnej z zakresu historii sztuki, zapewne często nieobce czytelnikowi. Niektóre składowe wiedzy nie są powszechnie znane, mimo że ich właściwa interpretacja nasuwa się sama. Jako przykład warto podać wyjaśnienie etymologii słowa „mozaika” - opus musaicum, jako „dzieła poświęconego muzom”, która koreluje z blaskiem dzieł sztuki tworzonych przez mozaicystów. Podobnie wprowadzenie do podstaw fotografii rozpoczyna zachęcające do dalszej lektury wyjaśnienie znaczenia tej techniki w języku greckim, jako „pisania” lub „rysowania światłem”. Dosłowny sens może umykać współcześnie, gdy fotografia jest tak powszechnym medium, a słowa z nią powiązane stosuje się także w języku codziennym. Omawiany tekst zawiera wiele cennych informacji. Warto nadmienić, że przedstawienie sztuki poszczególnych epok to właściwie wyjątkowe ujęcie w ramach Wstępu do historii sztuki. Zazwyczaj oddziela się nauczanie sztuki poszczególnych epok i technik sztuk plastycznych od zajęć i podręczników wprowadzających. Autorka zaprezentowała hasłowe, zawierające uogólnienia i wybrane przykłady przedstawienia poszczególnych zagadnień. Celem publikacji jest umożliwienie przyswojenia szerokiej problematyki powiązanej z historią sztuki, ukazanej w ujęciu problemowo-chronologicznym.

Książka Partsch to rodzaj podręcznego kompendium przede wszystkim dla osób dopiero rozpoczynających studia lub pragnących przygotować się do ich podjęcia. Nie mogło w niej więc zabraknąć utrzymanych w podobnym, definicyjno-praktycznym ujęciu zagadnień z zakresu muzealnictwa i ochrony zabytków. Autorka sformułowała także zasady, praktyki wielotorowych poszukiwań naukowych w obrębie dyscypliny, w której nieustannie splatają się ze sobą obraz i słowo. Co więcej, Partsch nie pominęła zasad i uwag odnoszących się do poszczególnych stopni studiów i następujących po nich karier - zawodowej lub naukowej. Liczne, krótkie podrozdziały kończą skrótowe wykazy pozycji bibliograficznych. Na końcu książki znajduje się użyteczna bibliografia.

Studia $z$ historii sztuki. Wprowadzenie z naciskiem na praktykę to tytuł trzech wydań książki Renate Prochno ${ }^{41}$. W otoku logo wydawnictwa Akademie Verlag umieszczono hasło Theoria cum praxi - „teoria i praktyka”. Autorka udziela początkującym, przede wszystkim młodym osobom, do których jest adresowana publikacja, wielu rad praktycznych. Książka stanowi właściwie usystematyzowany zbiór porad, przemyśleń i wyjaśnień, katalog praktyk wartych wdrożenia podczas studiów, który można określić jako obejmujący zdecydowaną większość aspektów studiowania. Naturalnie zdarza się, że nie wszystkie wskazówki są trafne, a tym bardziej nie wszystkie odpowiadają polskiemu systemowi szkolnictwa wyższego.

${ }^{41}$ Pierwsze wydanie: Renate Prochno, Das Studium der Kunstgeschichte: eine praxisbetonte Einführung (Berlin: Akademie Verlag, 1999). Trzecie wydanie: 2008. 
Wiele z nich zachęca do dyskusji, przedstawienia kontrargumentów. Dla przykładu: właściwie nie ma różnicy, czy publikacja zostanie przeczytana i opracowana w domu, czy - jak kilkakrotnie sugeruje autorka - w bibliotece. Podobnie nie ma znaczenia, czy student zapozna się z nią w wersji drukowanej, czy elektronicznej. Praca w bibliotece, korzystanie z czytelni i wypożyczalni uniwersyteckich, miejskich, pedagogicznych, zamiejscowych, zagranicznych, wypożyczalni międzybibliotecznej, bibliotek cyfrowych, a także księgarni to podstawa w kształceniu humanisty. Po zgromadzeniu obszernego materiału badawczego można nie tylko sformułować na jego podstawie pisemną wypowiedź, ale też nieco wcześniej - opracować go gruntownie w domowym zaciszu.

Prochno stara się ukształtować w osobach rozpoczynających kształcenie wyższe odpowiednie podejście do historii sztuki i samych studiów. Przedstawia obraz idealnego studenta historii sztuki, przede wszystkim pilnego, wnikliwie i świadomie czytającego, systematycznego, zorientowanego w materii nauki i we wszystkich, także najdrobniejszych, technicznych szczegółach studiowania, potrafiącego pracować samodzielnie i w zespole. Jest on świetnie zorganizowany, precyzyjny, podchodzi w wyważony sposób do nauki i prezentacji jej wyników. To student, który ma wszystko pod kontrolą. Modelowe, szczegółowo zaprezentowane w książce ramy studiów mogą jednak różnić się od tych zastanych w rzeczywistości.

Definicje poszczególnych zagadnień zostały podane w prosty, rzeczowy, pouczający sposób, poczynając od zupełnie podstawowych rzeczy. Wiele miejsca autorka poświęciła studiom uniwersyteckim, sposobom uczenia się. Nadmieniała również o uczelnianym savoir-vivrze, technikach pracy i radzeniu sobie z nieoczekiwanymi problemami komputerowymi. Ostatni, obszerny rozdział to z kolei poradnik nie dla uczących się, lecz dla nauczających na studiach wyższych, z którego pośrednio również mogą skorzystać studenci. Autorka omówiła w nim, jak prowadzić wykłady, zajęcia i dyskusje, nie zrazić ani nie urazić ich uczestników, a także jak efektywnie nauczać. Oprócz mających znaczenie poznawcze i historyczne informacji o systemie kształcenia, a także o technice sporządzania przypisów w Niemczech, w pracy pojawiają się również inspirujące, uniwersalne wskazówki. Niekoniecznie jednak należy skłaniać się do tego, by zapamiętywać wszystkie przedstawione reguły, jak również nie ma konieczności ścisłego trzymania się zaprezentowanych zaleceń. Ostatecznie bowiem każdy samodzielnie kształtuje swój warsztat, wiedzę i umiejętności oraz sposób myślenia. Tymczasem omawiane prace propedeutyczne i nauczyciele akademiccy mogą w tak ważnym procesie jedynie pomóc. Obok zawartych w tekście głównym propozycji dalszej lektury autorka dołącza do większości pozycji bibliograficznych krótki, jednozdaniowy bądź często rozbudowany, niemal całostronicowy komentarz. Proponuje publikacje przede wszystkim w języku niemieckim, ale też angielskim, francuskim i włoskim oraz strony internetowe i płyty CD.

Książka Prochno jest przeznaczona dla osób studiujących lub zamierzających podjąć studia z historii sztuki w Niemczech. Omawia szczegółowo system 
i strukturę kształcenia w zakresie tej dziedziny na niemieckich szkołach wyższych. Pewne elementy mogą jednak zostać uznane za przydatne także przez studentów z innych krajów. Książka przedstawia zagadnienia zazwyczaj w formie krótkich zdań, zawiera wiele bezpośrednich zwrotów do czytelnika, obrazowe, barwne, żartobliwe porównania. Autorka stosuje przemawiające do wyobraźni i łatwo przyswajalne sformułowania. Używa związków frazeologicznych lub wypowiedzi specyficznych dla nauki, ale o przysłowiowym charakterze.

Wprowadzenie do historii sztuki Huberta Schradego wydano już w 1966 r. w długiej serii „Urban Bücher” ukazującej się pod hasłem „Nauka w wydaniu kieszonkowym"42. Omawiana publikacja różni się od pozostałych przeanalizowanych ujęć brakiem wskazówek praktycznych, odniesień do technik studiowania oraz przeglądu metod badawczych przyjętych w historii sztuki. Autor najwięcej miejsca poświęcił zagadnieniom z zakresu mediewistyki i to od nich wyprowadzał swoje konstatacje. Podjęte problemy korelują z zainteresowaniami badawczymi Schradego i opublikowanymi przez niego książkami. Niewielki tom otwiera swobodna, zapewne mająca mieć charakter modelowej, dyskusja trojga uczestników konwersatorium $\mathrm{z}$ historii sztuki. Każda z osób ma inny poziom wiedzy i poglądy na temat omawianych dzieł sztuki wczesnośredniowiecznej. Rozmówcy wspierają swoje sądy dobranymi argumentami, niekiedy odnosząc się do współczesności i ogólnych przekonań, wyraźnie artykułują swoje stanowiska. Zestawienia na zasadzie opozycji formalnej i tożsamości ikonograficznej nieodległych czasowo i przestrzennie dzieł sztuki przedstawiającej uwidaczniają, jak bardzo dynamiczne zmiany zachodziły w sztuce średniowiecznej. Z rozważań autora można wyciągnąć wniosek, że obiektów artystycznych powstałych w dowolnej epoce artystycznej nie można traktować en bloc. Książka Schradego stawia ważne pytania odnośnie do istoty historii sztuki, dzieł sztuki, ich postrzegania naukowego, artystycznego i estetycznego, zarówno przez historyków sztuki, jak i - na podstawie historycznych przekazów - przez poetów, teologów, polityków itp. Autor podaje też odpowiedzi na zagadnienia pojawiające się $\mathrm{w}$ toku czytania swobodnie skonstruowanego wywodu. Oś kompozycyjną książki stanowią łącznie trzy - mające formę rozdziałów - rozmowy adeptów historii sztuki. Autor w publikacji skupił się na sztuce chrześcijańskiej, powstaniu obrazu chrześcijańskiego i kontrowersjach z nim związanych. Przedstawił ponadto tłumaczenie protokołu posiedzenia francuskiej Królewskiej Akademii Malarstwa i Rzeźby. Źródło zawiera dyskusję na temat stylistyki, ikonografii, odpowiedniości ujęcia przedstawionych elementów oraz zgodności z Biblią obrazu Nicolasa Poussina. Do tego świadectwa estetyki końca XVII stulecia odniosą się z perspektywy lat sześćdziesiątych XX w. adepci historii sztuki podczas kolejnej przedstawionej dyskusji na konwersatorium. Autor, omawiając wkład Giorgia Vasariego, Jeana-Jacques’a Rousseau oraz Johanna Wolfganga Goethego, ponownie podejmuje kwestie historyzującego podejścia do estetyki i recepcji

${ }^{42}$ Hubert Schrade, Einführung in die Kunstgeschichte (Stuttgart: W. Kohlhammer Verlag, 1966). 
sztuki. Wskazuje związki między sztuką a rzeczywistością. Jedna z zaprezentowanych propozycji dotyczy kształtowania na nowo świata realnego w dziełach sztuki, a nie naśladowania go $\mathrm{w}$ prosty sposób.

Podczas badań z zakresu historii sztuki nasuwa się pewna konstatacja. Sztuka przemawia do odbiorców nawet wtedy, gdy artysta pozostaje nieznany. Kwestia pochodzenia pozostaje sprawą drugorzędną. Podobnie nie trzeba weryfikować biografii Ludwiga van Beethovena, by podziwiać, opisywać, porównywać i rozumieć jego muzykę. Dla przykładu: nie musimy wiedzieć nic o dyrygencie Rudolfie Kempe i składzie filharmonii monachijskiej podczas nagrania II i VII symfonii Beethovena, by odbierać je estetycznie oraz znajdować podobieństwa pomiędzy muzycznymi interpretacjami. Każdy muzyk odciska swe piętno na zespole dźwięków składających się na dane wykonanie symfonii. Mimo to zazwyczaj zaledwie kilka nazwisk znajduje się w broszurze dołączanej do płyty. Także w przypadku oper wymienia się, oprócz nazwiska dyrygenta, tylko solistów. Nie można jednak poprzestać na czystej formie dzieła sztuki. Omawiane Wstępy do historii sztuki, pojmowane jako całość, pozwalają lepiej, z większą świadomością różnorodności ujęć badawczych, spojrzeć na kolejne, także nieomówione w nich obiekty artystyczne i wzbogacić własną wiedzę.

Studiowanie historii sztuki przypomina pod pewnym względem naukę języków obcych, a zwłaszcza chemii, fizyki i matematyki, dokonywaną poprzez skrupulatne rozwiązywanie zbiorów zadań, któremu towarzyszy zainteresowanie i pasja. Aby uprawiać historię sztuki, należy przede wszystkim rozwiązać szereg humanistycznych problemów. Zakres i przemyślenia rozwija się z roku na rok.

Książkowe wprowadzenia do historii sztuki mogą stanowić cenne uzupełnienie kształcenia. Nie można jednak zapomnieć, że istotą studiowania jest tak naprawdę praktyczne mierzenie się z kolejnymi problemami i obiektami artystycznymi. Różnie można traktować przedmiot badań oraz stosować odmienne ujęcia treści formalnych i ideowych. Do większości przypadków odnosi się jednak stwierdzenie pojawiające się w artykule Tadeusza J. Żuchowskiego i Jana Skuratowicza „nie powinno się uprawiać historii sztuki bez dzieła sztuki”" czenie, gdyż wskazuje na symbiozę wniosków płynących z prac teoretycznych $\mathrm{z}$ własnymi zmaganiami $\mathrm{z}$ dziełem sztuki $\mathrm{w}$ terenie. $\mathrm{W}$ tym przypadku wniosek dotyczy świeckich, reprezentacyjnych zabytków architektonicznych w Wielkopolsce czasów Jagiellonów: „Teorie mogą określić i pozwolić interpretować zjawiska, ale materia winna zostać przebadana, cegła po cegle" ${ }^{\prime 4}$.

Zapoznanie się z jednym, monograficznym ujęciem Wstępu do historii sztuki z pewnością okaże się niewystarczające, niekompletne. Studenci, pisząc prace podczas studiów czy biorąc udział w zajęciach, zaznajamiają się z różnorodnymi

43 Jan Skuratowicz, Tadeusz J. Żuchowski, „Rozważania wokół pierwszego przykazania”, Artium Quaestiones 20 (2009): 217.

$44 \quad$ Ibidem, 229. 
ujęciami tego samego zagadnienia, argumentacjami, dyskursem, kontrowersjami, podsumowują wyczerpujące stany badań. Warto, by czerpali z wielu źródeł wiedzę metodyczną odnośnie do właściwego wykorzystania czasu, lektur oraz pomocy wykładowców podczas łącznie pięciu lat studiów pierwszego i drugiego stopnia. Przedstawione Wprowadzenia do historii sztuki z pewnością pomogą ukształtować ich osobowość jako historyków sztuki.

\author{
Przemysław Waszak \\ Introduction to the history of art - review of latest literature
}

\begin{abstract}
Summary
The subject of the article is analysis of ways of acquainting students with art history studies. The article shows how the monographs help to improve the gradually more and more independent steps in the world of art history. The analysed students' handbooks certainly allow to shape the personality of future art historians. The discussed books - introductions to the history of art - permit the reader to gain a better awareness of diverse scientific approaches and methodologies. Furthermore, they show ways of increasing knowledge and getting more skills during the reader's own art history studies. They present many useful both theoretical and practical thoughts and instructions. The article explains the most important message of each book and considers the proposed methods. Examples as well as comparisons are shown. Reading only one monograph on the title subject would be insufficient. Studying the humanistic course and conducting research in the field of art history requires receptiveness to different views. Therefore, the article examines in detail a few publications written in German and one in English. They have similar titles, but their perspective, content and vision of studies are in each case original and independent.
\end{abstract}

